\title{
SYMMETRICAL PERIPHERAL OEDEMA IN INFANTS
}

\author{
BY \\ H. EVERLEY JONES \\ From the Children's Department, the Royal Hospital, Wolverhampton
}

(RECEIVED FOR PUBLICATION JUNE 2, 1959)

Oedema is a common occurrence in newborn infants, particularly when they are premature. The seven patients, brief clinical accounts of whom appear below, appear to fall into a separate group.

\section{Case Reports}

Case 1. A male child was born in 1949 at term following a normal pregnancy and labour. His birth weight was $9 \frac{1}{2} \mathrm{lb}$. Swelling of the feet was noted soon after birth. He was breast fed for two months and then reared on dried milk.

On examination at the age of 6 weeks symmetrical pitting oedema of both feet extending a short distance up the legs was present. The hands were spared and no other abnormalities were found. B.P. was $80 / 50$.

INVESTIGATIONS. Urine was repeatedly negative for albumin and deposit.

Hb was $70 \%$, R.B.C. $3,500,000$ per c.mm., W.B.C. 12,600 per c.mm. (neutrophils $44 \%$, lymphocytes $49 \%$, eosinophils $2 \%$, monocytes $6 \%$ ).

Plasma proteins were $6.5 \mathrm{~g}$. per $100 \mathrm{ml}$. (albumin 4.6 g. per $100 \mathrm{ml}$., globulin 1.9 g. per $100 \mathrm{ml}$.). Blood urea was $30 \mathrm{mg}$. per $100 \mathrm{ml}$.

Biopsy from the dorsum of the foot showed that the epidermis was rather thin with oedema. The rete pegs were somewhat diminished and the corium a little thickened with some increase of collagen. There was slight perivascular infiltration with lymphoid cells.

The oedema had vanished by the age of 18 months, while growth and development proceeded normally. When last seen at the age of 8 years the child was obese, weight $100 \mathrm{lb}$. (mean $59 \frac{1}{2} \mathrm{lb}$.), height $55 \mathrm{in}$. (mean $50 \mathrm{in}$.), but was otherwise normal.

Case 2. This girl was an only child, although the mother had had two previous miscarriages. She was born in 1950, two weeks prematurely, after an uneventful pregnancy with a birth weight of $6 \mathrm{lb}$. The mother was stated to have had slight swelling of the left foot all her life, and her mother was said to have had oedema of the feet for many years. No swelling was found in the case of the mother, and the grandmother had bilateral but unequal oedema of the feet associated with varicose veins. Both women appeared otherwise healthy.

On examination at the age of 6 weeks the child was healthy apart from symmetrical pitting oedema of the feet and lower legs, which tapered off about half-way to the knees. The hands were affected to a lesser degree.

INVESTIGATIONS. Urine was free from albumin and abnormal deposit and there was no abnormal aminoaciduria.

Hb was $80 \%$, R.B.C. $4,500,000$ per c.mm., W.B.C. 11,200 per c.mm. (neutrophils $43 \%$, lymphocytes $51 \%$, monocytes $6 \%$ ). Blood urea was $35 \mathrm{mg}$. per $100 \mathrm{ml}$., blood calcium $11 \cdot 2 \mathrm{mg}$. per $100 \mathrm{ml}$., serum phosphorus $5.6 \mathrm{mg}$. per $100 \mathrm{ml}$. Plasma proteins were $6 \mathrm{~g}$. per $100 \mathrm{ml}$. (albumin $4 \mathrm{~g}$. per $100 \mathrm{ml}$., globulin $2 \mathrm{~g}$. per $100 \mathrm{ml}$.$) .$

The oedema finally disappeared at the age of 4 years. She remained healthy apart from pneumonia when 7 years old. When seen at the age of 8 years a scraping of the buccal mucosa showed a female chromatin pattern. She was small, weight $46 \mathrm{lb}$. (mean $58 \mathrm{lb}$.), height $45 \mathrm{in}$. (mean $49 \frac{1}{2}$ in.), and the only other abnormality found was dystrophy of the little toenails. Bone age at this time was one to two years behind the chronological age.

Case 3. This girl, a third child, was born in 1951, the older two siblings being normal. She was said to have been born at term, but weighed only $4 \mathrm{lb} .11 \mathrm{oz}$. at birth. Pregnancy and labour were normal. Her feet and hands were noticed to be swollen at birth. She was fed from birth on dried milk.

When examined at the age of 2 months she weighed $7 \mathrm{lb} .2 \mathrm{oz}$. She had symmetrical pitting oedema of the feet and lower parts of the legs and the hands. There was slight webbing of the neck, a low hair-line, high arched palate and rudimentary nails. Signs of coarctation of the aorta were present.

INVESTIGATIONS. Urine was repeatedly normal. Blood urea was $38 \mathrm{mg}$. per $100 \mathrm{ml}$., serum cholesterol $135 \mathrm{mg}$. per $100 \mathrm{ml}$. Wassermann reaction was negative, and a chest radiograph was normal. Radiological bone age was normal (aged 7 years). A scraping of the buccal mucosa at the age of 6 years was chromatin-negative, suggesting the male sex.

When last seen at the age of 7 years she was mentally retarded and was attending an occupation centre. Her height was $44 \mathrm{in}$. (mean $47 \mathrm{in}$.) and her weight was $48 \mathrm{lb}$. (mean $51 \frac{1}{2} \mathrm{lb}$.). The oedema of the hands disappeared in the first year, but that of the feet lingered until she was 5. The other abnormal features were more pronounced, and the chest was broad with widely spaced 
nipples. The signs of coarctation of the aorta were present with blood pressure in the arms $150 / 90$ while the femoral pulses were not felt.

Case 4. A female child was born in 1954, two weeks prematurely, after an uneventful pregnancy. Her weight at birth was $6 \frac{3}{4} \mathrm{lb}$. She is the third child and the two older children are normal. She was admitted to hospital at the age of 6 weeks on account of a respiratory infection.

On examination there was symmetrical pitting oedema of the feet and lower parts of the legs and of the hands and wrists, which the mother stated had been present from birth. In addition slight webbing of the neck was present and she had dystrophy of the toenails.

INVESTIGATIONS. Urine was normal with no abnormal amino-aciduria. $\mathrm{Hb}$ was $85 \%$. The plasma proteins rose from a total of $4 \cdot 8 \mathrm{~g}$. per $100 \mathrm{ml}$. at 2 months to $6.5 \mathrm{~g}$. per $100 \mathrm{ml}$. at the age of 1 year. On each occasion the electrophoretic pattern showed a normal proportion of albumin and globulin. Serum bilirubin was $0.3 \mathrm{mg}$. per $100 \mathrm{ml}$., serum alkaline phosphatase $21 \cdot 5 \mathrm{~K}$.A. units, thymol turbidity 1 unit, serum sodium $320 \mathrm{mg}$. per $100 \mathrm{ml}$, serum calcium $10.6 \mathrm{mg}$. per $100 \mathrm{ml}$., serum phosphorus $6 \mathrm{mg}$. per $100 \mathrm{ml}$.

Examination of a scraping of buccal mucosa showed that the chromatin pattern was of male type.

The oedema of the hands disappeared by the age of 12 months, but that of the feet continued until she was nearly 3 years old. With the passage of time other abnormalities became apparent, notably low hair line, 'shark' mouth, ear deformities, anti-Mongolian slant to the eyes and broad chest with widely spaced nipples. She has remained small and at the age of 3 years 11 months weighed $25 \frac{1}{2} \mathrm{lb}$. (mean $35 \frac{1}{2} \mathrm{lb}$.) and was $36 \frac{1}{2}$ in. in height (mean $39 \frac{3}{4}$ in.). The blood pressure has always been normal and the bone age has corresponded with the chronological age.

Case 5. This boy was the third child of healthy parents. The two older siblings were healthy. He was born normally at term in 1954 after an uneventful pregnancy, his weight at birth being $7 \mathrm{lb}$. Symmetrical oedema of the feet and lower parts of the legs and, to a lesser degree, of the hands was noticed just after birth. The only other abnormality observed was dystrophy of the toenails.

INVESTIGATIONS. Urine was free from abnormal constituents and there was no unusual amino-aciduria. Hb was $90 \%$, W.B.C. 6,500 per c.mm. (neutrophils $45 \%$, lymphocytes $45 \%$ ). Blood urea was $34 \mathrm{mg}$. per $100 \mathrm{ml}$. and the plasma proteins varied from $5.9 \mathrm{~g}$. per $100 \mathrm{ml}$. at 2 months of age to $6.9 \mathrm{~g}$. per $100 \mathrm{ml}$. at 8 months. The albumin/globulin ratio and electrophoretic pattern were normal on each occasion.

Biopsy from the dorsum of the foot showed rather thick epidermis with somewhat marked keratinization. The corium showed no inflammatory reaction.

Examination of a scraping of the buccal mucosa showed a chromatin pattern of male type.

Since then he has developed normally and the oedema finally disappeared by the age of $3 \frac{1}{2}$ years. At 4 years of age he was small, weighing $31 \frac{1}{2} \mathrm{lb}$. (mean $37 \frac{1}{2} \mathrm{lb}$.) and his height was $36 \frac{1}{2}$ in. (mean 40 in.). The bone age was equivalent to his chronological age and the highest blood pressure recorded was $90 / 50$.

Case 6. The only child of healthy parents, this girl was born in 1955 at term after a normal pregnancy and labour, her birth weight being $8 \frac{1}{2} \mathrm{lb}$. Symmetrical pitting oedema of the feet, lower legs and hands was noted at birth. The only other abnormalities found were a defect of the left pinna and dystrophy of the toe-nails, especially of the little toes. She was fed on dried milk from birth.

INVESTIGATIONS. Urine was repeatedly free from albumin and abnormal deposit and amino-aciduria was normal for her age.

Blood urea was $40 \mathrm{mg}$. per $100 \mathrm{ml}$, serum sodium $310 \mathrm{mg}$. per $100 \mathrm{ml}$. and serum potassium $22 \mathrm{mg}$. per $100 \mathrm{ml}$. The plasma proteins were $5.9 \mathrm{~g}$. per $100 \mathrm{ml}$. (albumin 3.9 g. per $100 \mathrm{ml}$., globulin 2.0 g. per $100 \mathrm{ml}$.). The electrophoretic pattern was normal and the Wassermann reaction was negative.

The chromatin pattern from a scraping of buccal mucosa suggested the female sex.

At the age of 2 weeks adrenocorticotrophin, 10 units of the gel daily, was tried. This was stopped after three days as the oedema became more marked.

She has since developed normally both mentally and physically. Her blood pressure has never been raised, and when last seen at the age of 3 years 2 months it was $90 / 50$. At that time she weighed $35 \mathrm{lb}$. (mean $31 \mathrm{lb}$.) and her height was 36 in. (mean $37 \frac{1}{2}$ in.). The oedema of the feet was still present though less marked. That of the hands had cleared by the age of 3 years. Her bone age was normal.

Case 7. This girl was the fifth child of healthy parents; the four elder siblings were quite healthy. She was born in 1955 at term, birth weight $5 \mathrm{lb}$., following a normal pregnancy and labour. Swelling of the feet was noticed at birth and the hands were stated to be swollen at intervals. She was fed on dried milk from birth.

On examination at 2 months of age she had symmetrical pitting oedema of the feet extending about half-way up the legs towards the knees. Mild pitting oedema of the backs of the hands was also present. In addition slight cyanosis of the nail beds and dystrophy of the toe-nails were seen. No other abnormalities were found.

INVESTIGATIONS. Urine was repeatedly free from albumin and abnormal constituents and there was no unusual amino-aciduria.

Hb was $85 \%$, W.B.C. 6,500 per c.mm. (neutrophils $50 \%$ ). Blood urea was $40 \mathrm{mg}$. per $100 \mathrm{ml}$., serum cholesterol $120 \mathrm{mg}$. per $100 \mathrm{ml}$., E.S.R. $12 \mathrm{~mm}$. in one hour (Wintrobe). The plasma proteins were $6.4 \mathrm{~g}$. per $100 \mathrm{ml}$. (albumin $4 \cdot 2 \mathrm{~g}$. per $100 \mathrm{ml}$., globulin $2 \cdot 2 \mathrm{~g}$. per $100 \mathrm{ml}$.). The electrophoretic pattern was normal.

A skin biopsy from the dorsum of the foot showed hyperkeratosis and mild parakeratosis with slight acanthosis. The deepest vessels of the corium were invested by an infiltrate of tissue cells, a few plasma cells and neutrophils. 
A scraping of the buccal mucosa was taken at the age of 2 years. The chromatin pattern was of male type.

When last seen at the age of 3 years 4 months her height was $31 \frac{1}{2}$ in. (mean 38 in.) and she weighed $23 \frac{1}{2} \mathrm{lb}$. (mean $331 \mathrm{lb}$.). Her blood pressure was $100 / 60$. The bone age was normal. Slight oedema of the feet only remained.

All these children had one feature in common, namely oedema, always of the feet and usually to a lesser degree of the hands, which had been present from birth. Pitting was always present and there was no discolouration of the skin nor evidence of circulatory disorder. The swelling of the lower extremities presented a rather typical appearance, being most marked over the dorsa of the feet. It tapered away up the legs to finish below the knees, resembling well-fitting field boots. It was always symmetrical. The oedema tended to disappear from the hands first, and to vanish from the legs in the first few years of life. In five children it has disappeared completely, while in two, both aged 3 years, it is still present but decreasing.

The marked similarity of the swelling without constitutional upset in all these seven patients suggests that all are suffering from the same disease, which has not occurred in other members of their families. In one instance the mother and grandmother were said to have suffered from swelling of the feet but no oedema was found in the case of the mother while the grandmother's oedema was associated with varicose veins, quite unlike the self-limiting disease seen in these children.

Of these seven children, five were undersized for their age when examined in later years. Despite the inferior growth, in only one of them was there a retardation in bone age (one to two years at the age of 8).

Five showed dystrophy of the toenails. This was confined to the toes and was most marked in the little toes. It was always symmetrical. The nails were small, deformed and had a brown hue.

Finally, in three of the five girls examination of the chromatin of the cells in a scraping of buccal mucosa showed the nuclear sex to be male. In the other two girls and the two boys the chromatin pattern corresponded with the morphological sex.

\section{Discussion}

The usual causes of oedema in the young infant can be dismissed. There was no evidence of heart or kidney disease, and prematurity was not a factor. Hypothermia was not seen and arthritis was not a feature.

Besides these well-known types of oedema the earlier literature contains records, often in the form of single case reports, of oedema involving the extremities of newborn children. Confusion resulted from the use of such terms as 'trophic' and 'lymphangiectatic' oedema, 'scleroedema' and 'elephantiasis'.

Three names are particularly associated with these early accounts.

Nonne (1892) described a family with swellings of the lower limbs which were firm, fleshy and nonpitting (congenital hereditary elephantiasis).

Milroy (1892) gave an account of 22 persons among 97 members of one family with congenital 'trophic' oedema of the extremities. The condition was hereditary, permanent and unaccompanied by constitutional disease. The oedema affected one or both legs and might extend up to Poupart's ligament but not beyond. In 21 of the 22 cases the condition was present at birth.

Meige (1898) wrote of a family of eight, whose members suffered from chronic oedema of the legs. The condition was not congenital and usually appeared at about puberty.

Volz (1938) gave a summary of the literature on oedema of the newborn baby up to that time, and described an infant similar to those described here. In addition his patient had bilateral epicanthus and loose skin at the nape of the neck. He listed 12 other somewhat similar cases recorded up to that date.

From this clinical medley Mason and Allen (1935) differentiated one group which they called congenital simple lymphoedema. They described five patients in each of whom the oedema was congenital, affected one limb only and was persistent. The unilaterality and non-familial incidence differentiated them from congenital, familial lymphoedema or Milroy's disease, of which they confessed they had yet to see an example.

The histological features of their cases were characteristic. The subcutaneous fat was replaced by enlarged lymphatic vessels and by fibrous tissue.

These features exclude such a diagnosis in these seven children in whom the oedema was always symmetrical and in whom biopsy failed to reveal the characteristic findings.

$/$ Bonnevie $(1932,1934)$ showed that multiple malformations of the head and extremities appeared as a recessive trait in a race of $\mathrm{X}$-rayed mice-BaggLittle strain (Bagg and Little, 1924). She showed that these deformities arose as a result of the excessive escape of cerebrospinal fluid through the anterior foramen, an opening in the roof of the fourth ventricle. This excess fluid accumulated as myencephalic blebs in the neck and then migrated 
under the epidermis and eventually reached the extremities. Abnormalities resulted from the effects of pressure caused by these accumulations.

Ullrich (1936) adapted this theory to explain a number of apparently unconnected congenital defects in the human being. These were particularly unilateral deficiency of the pectoral muscles and motor cranial nerve defects as well as various abnormalities of the hand (club-hand). They were attributed to arrest in the migration of myencephalic blebs. He also considered that unilateral webbing of the neck, congenital lymphangiectatic oedema and certain other defects, such as dystrophic nails and hypoplastic nipples, should be included in the wandering bleb hypotheses. These abnormalities were grouped together as the status BonnevieUllrich, asymmetrical type.

In succeeding years this conception was expanded and, under the title of symmetrical status BonnevieUllrich, a number of seemingly diverse defects was assembled. The most important of these was bilateral webbing of the neck (pterygium colli) accompanied by low hair line, preference for the female sex, loose skin, epicanthus, sagging eyelids, 'shark' mouth, abnormalities of the ears, high arched palate, cubitus valgus, defects of the nails, some degree of dwarfism and sexual infantilism, 'mushroom' epiphyses of the long bones, increased digital markings of the skull and oedematous swellings of the neck and extremities at birth which tend to disappear with the passage of time (Ullrich, 1949). Ullrich has since conceded that the wandering bleb hypotheses can no longer be regarded as applicable to the symmetrical, as opposed to asymmetrical, type of the status.

Independently Turner (1938) described seven girls from 15 to 23 years of age, each of whom showed a triad of infantilism, webbing of the neck and elbow deformity. As Ullrich remarked, these features comprise only some of the characteristics included by European authors in the symmetrical form of status Bonnevie-Ullrich. Yet writers of the English-speaking nations commonly refer to this complex as Turner's syndrome.

In the last 10 years further additions to the status have been suggested (Rossi and Caflisch, 1951; Silver, Kiyasu, George and Deamer, 1953). Terminology has been varied and largely centred on the question of sexual infantilism. The latter has received much interest since the demonstration by Moore, Graham and Barr (1953) that the genetic sex of body cells may be determined by a study of the nuclear chromatin. Use of this technique has shown that the majority of the affected patients, though morphologically girls, are genetically of the male sex and have gonadal hypoplasia. In children examination of sections of the skin or scrapings of the buccal mucosa have enabled a correct diagnosis to be made before the absence of the normal changes occurring at puberty would draw attention to the condition. Examples in early life have been described by Silver (1956) and Grumbach (1957). The patients of both these authors had oedema of the feet in early infancy, which gradually disappeared.

Grumbach remarked that there is a group of young patients of either sex with a varied number of congenital defects, as described by Ullrich and Turner, in whom testes or ovaries are present normally. In these children gonadal and chromatin sex correspond and normal secondary sexual changes occur at puberty. He suggested that these patients should be grouped under the title of TurnerUllrich syndrome to differentiate them from those, nearly all female, who also have gonadal atrophy, usually with male sex chromatin, whom he would label simply as gonadal dysgenesis.

As might be expected in a syndrome combining so many different defects, many examples are incomplete. In three of the seven children described here the appearances came to be characteristic of the symmetrical type of the status. The demonstration of cytological male sex in morphological females showed that they belonged to the gonadal dysgenesis group. The oedema present in the other four was identical with that seen in these three. In addition some other of the described features, such as small size or dystrophy of the nails, were usually present, and it is suggested that they are incomplete forms of the status and should be included in the Turner-Ullrich syndrome.

\section{Summary}

Seven children, each of whom showed symmetrical peripheral oedema of the lower extremities and usually of the upper extremities to a lesser degree, are described.

Four of them are considered to be examples of the symmetrical type of status Bonnevie-Ullrich in incomplete form, while the remaining three, all girls, are examples of the more complete form, also known as Turner's syndrome or gonadal dysgenesis.

When children show this clinical picture it is advisable to determine the genetic sex by examination of the nuclear chromatin.

Thanks are due to Dr. A. G. Marshall for pathological investigations and to Dr. Alan Booth for radiological examinations. 


\section{REFERENCES}

Bagg, H. J. and Little, C. C. (1924). Hereditary structural defects in the descendants of mice exposed to roentgen ray irradiation. Amer. J. Anat., 33, 119.

Bonnevie, K. (1932). Zur Mechanik der Papillarmusterbildung; Anomalien der menschlichen Finger- und Zehenbeeren, nebst Diskussion über die Natur der hier wirksamen Epidermispolster. Arch. Entwickl. Mech. Org., 126, 348.

(1934). Embryological analysis of gene manifestation in Little and Bagg's abnormal mouse tribe. J. exp. Zool.,67, 443.

Grumbach, M. M. (1957). Chromosomal sex and the prepuberal diagnosis of gonadal dysgenesis. Pediatrics, $20,740$.

Mason, P. B. and Allen, E. V. (1935). Congenital lymphangiectasis (lymphedema). Amer. J. Dis. Child., 50,945.

Meige, H. (1898). Dystrophie oedémateuse héréditaire. Presse méd., 6, (2), 341. Milroy, W. F. (1892). An undescribed variety of hereditary oedema.
N.Y. med. J., 56, 505 .

Moore, K. L., Graham, M. A. and Barr, M. L. (1953). The detection of chromosomal sex in hermaphrodites from a skin biopsy. Surg. Gynec. Obstet., 96, 641 .
Nonne, M. (1892). Vier Salle von Elephantiasis congenita hereditaria. Virchows Arch, path. Anat., 125, 189.

Rossi, E. and Caflisch, A. (1951). Le syndrome du pterygium; status Bonnevie-Ulirich, dystrophia brevicolli congenita, syndrome de Turner et arthromyodysplasia congenita. Helv, paediat. Acta, 6, 119 .

Silver, H. K. (1956). Symmetric form of Bonnevie-Ullrich syndrome Pediatrics, 17, 725.

-, Kiyasu, W., George, J. and Deamer, W. C. (1953). Syndrome of congenital hemihypertrophy, shortness of stature and elevated gonadotropins. Ibid., 12, 368 .

Turner, H. H. (1938). A syndrome of infantilism, congenital webbed neck, and cubitus valgus. Endocrinology, 23, 566

Ullrich, O. (1936) In Bumke, O and Foerster, Handbuch der Neurologie, Vol. 16, p. 139. Springer, Berlin.

(1949). Turner's syndrome and status Bonnevie-Ullrich. A synthesis of animal phenogenetics and clinical observations on a typical complex of developmental anomalies. Amer. J. hum. Genet., 1, 179 .

Volz, H. (1938). Odeme bei Neugeborenen. Z. Geburtsh. Gynäk., $117,131$. 